\title{
Bone regeneration in mandible defect with autograft bone and cell suspension from bone marrow in rabbits
}

\author{
[Regeneração óssea em defeitos mandibulares com auto-enxerto ósseo e suspensão \\ celular da medula óssea em coelhos] \\ C. Gomes ${ }^{1}$, A.H. Paz ${ }^{2}$, A.T. Bonilla ${ }^{3}$, A. Corrêa ${ }^{3}$, R.L. Cavalcante ${ }^{3}$, D. Veiga ${ }^{3}$, L.M. Colomé $e^{4}$, \\ L.P. Foerstnow ${ }^{3}$, E.A. Contesini ${ }^{3}$, E.O. Cirne-Lima ${ }^{2,3}$ \\ ${ }^{1}$ Programa de Pós-Graduação em Medicina Veterinária - Universidade Federal de Santa Maria \\ Av. Ramiro Barcelos 2350, Bairro Santa Cecília \\ 90035-903 - Porto Alegre, RS \\ ${ }^{2}$ Laboratório de Embriologia e Diferenciação Celular - Hospital de Clínicas de Porto Alegre, RS \\ ${ }^{3}$ Faculdade de Veterinária - Universidade Federal do Rio Grande do Sul, RS \\ ${ }^{4}$ Escola de Veterinária - Universidade de Passo Fundo - Passo Fundo, RS
}

\begin{abstract}
The objective of this study was to investigate the bone regeneration of a "gold standard" (autograft) from iliac crest associated with cellular therapy in rabbits. A bone defect was created with $10 \times 5 \times 5 \mathrm{~mm}$ in 28 rabbit mandibles. The control group animals $(n=14)$ were repaired with autograft of iliac crest and the experimental group animals $(n=14)$ received iliac crest autograft in association with mononuclear cells from the bone marrow of the femur. Weekly radiographs were taken of the surgery region and histological analyses was performed in seven animals in each group at 15 days and in seven animals of each group at 30 days after the surgery. A gradual increase of bone density was observed and the experimental animals presented the bone bridge in $85.7 \%$ (6/7) of the cases, while only $42.8 \%$ (3/7) of the animals in the control group presented this structure 28 days after the surgery. The histopathological parameters analyzed did not show any statistical difference between the control and experimental group in 15 and 30 days of analysis. The results suggest that the mononuclear cells from the marrow bone can better support the autograft regeneration in mandible defects in rabbits.
\end{abstract}

Keywords: rabbit, mandibular reconstruction, bone regeneration, graft

\section{RESUMO}

Avaliou-se a regeneração óssea de auto-enxerto, considerado "padrão ouro" da crista ilíaca associado à terapia celular da medula óssea em coelhos. Foi criado um defeito ósseo de $10 \times 5 \times 5 \mathrm{~mm}$ na mandíbula de 28 coelhos, distribuídos em grupo-controle com, 14 animais, reparados com auto-enxerto de crista ilíaca, e grupo experimental com, 14 animais, em que o auto-enxerto foi associado a células mononucleares da medula óssea autógena do fêmur. Foram realizadas radiografias semanais da região operada e análise histológica em sete animais de cada grupo aos 15 e em sete de cada grupo aos 30 dias do pós-operatório. Houve aumento gradativo da densidade óssea, e 85,7\% (6/7) dos animais do grupo experimental e 42,8\% (3/7) do grupo-controle apresentaram formação de ponte óssea 28 dias após a cirurgia. Na análise histopatológica aos 15 dias, os enxertos foram facilmente visualizados e a atividade das células fagocitárias foi intensa. Já aos 30 dias, a visualização foi mais difícil e, quando possível, apenas um resquício foi visualizado. Os resultados sugerem que a adição de células mononucleares da medula óssea favorece a regeneração do auto-enxerto em defeitos mandibulares de coelhos.

Palavras-chave: coelho, reconstrução mandibular, regeneração óssea, enxerto

Recebido em 12 de maio de 2010

Aceito em 8 de junho de 2011

E-mail:crisgomes98@hotmail.com 


\section{INTRODUCTION}

Mandible bone defects in both human beings and animals may be caused by the removal of neoplasia, by trauma and infections or constitute congenital deformities. The sizes of defects vary considerably, from small alveolar fissures to conditions resulting from mandibulectomy (Yeh and Hou, 1994; Ellis, 2005).

The techniques of mandibular reconstruction have represented a challenge to buccalmaxillary-facial surgeons and orthopedists ( $\mathrm{Li}$ and $\mathrm{Li}, 2005$ ). For filling up the defect, autograft, allograft or xenograft are usually applied, with the first presenting the best results, since it does not produce rejections and contains live cells (Gandelmann et al., 2003). A short period to recover the oral function is extremely important for a better food grasp, chewing and deglutition. Besides, the gap produced shows difficult healing, mainly in old-aged people and animals, whose tumor frequency is higher and bone healing is slower (Ellis, 2005).

The potential use of both embryonic and adult stem cells has been extended to other areas. Several studies have lately reported new perspectives regarding cell treatments in reconstructive medicine. However, the ethical question involving the use of embryonic stem cells and the risk of teratocarcinoma still requires a precautious procedure and has focused the studies on adult cells (Jones and Trainor, 2004; Sylvester and Longaker, 2004).

The stem cells act on bone reparation and reconstruction with the cell replication and differentiation, production of regenerative cytokines and structural matrix, which fulfill the mechanical demands for bone function restoration (Kraus and Kirker-Head, 2006). They have demonstrated capability to enhance the osteoinduction effect, provide bone progenitor cells, and enable growth factors that intensify the osteoinduction activity (Rizzo et al., 2005). This study contributes to the assessment of the bone healing time in mandibular defect experimentally induced in rabbits, using autograft from iliac crest that are considered a "gold standard" graft associated with a transplant of cell suspension from autogenous bone marrow.

\section{MATERIAL AND METHODS}

The study investigated 28 healthy New Zealand white rabbits (Oryctolagus cuniculus) of average body mass around $3 \mathrm{~kg}$ and approximately 90 days of age. The animals were clinically evaluated and kept in individual cages, where they were fed with commercial rabbit food. This study was approved by the Ethics Committee of the Hospital de Clínicas de Porto Alegre (HCPA), protocol 06402.

The sample was defined with fixed " $n$ " of seven rabbits per group. With this number of animals in each group, the difference was analyzed between the median values of healing scores from two standard deviations corresponding to a high effect size considering $\alpha=0.05$ and $90 \%$ power. All 28 rabbits were randomly separated into four groups of seven animals: control group, whose animals were killed on the $15^{\text {th }}$ day (CG15) or $30^{\text {th }}$ day (CG30), and cortical sponge autograft group associated with cell suspension from autogenous bone marrow, whose animals were killed on the $15^{\text {th }}$ day (BMG15) or $30^{\text {th }}$ day (BMG30).

All rabbits had their lower left incisive tooth pulled out and the minimum period of 50 days for the dental alveolus recovery was observed in order to release the region for the bone defect procedure. The collection process of bone marrow cells from the BMG rabbits occurred before starting the surgery. The collection was performed through percutaneous puncture using a 40x12 hypodermic heparin-flushed needle, which was penetrated into the trochanteric fossa towards the marrow canal.

The minimum volume collected was $2 \mathrm{~mL}$ per animal. The total amount of bone marrow aspirated from the rabbits' femurs was processed with Ficoll-paque to separate the mononuclear fraction. For this process, the total amount of bone marrow aspirated was initially homogenized and flushed twice using D-MEM culture medium with $10 \%$ fetal bovine serum and $1 \%$ penicillin. The cell suspension was centrifuged for 5 minutes at 2,000rpm. After centrifugation, the pellet of cells was suspended again in $3 \mathrm{~mL}$ of complete D-MEM culture medium. The cell suspension was added to another tube with $3 \mathrm{~mL}$ of Ficoll-hypaque. The cells were centrifuged for 20 minutes at 
1,500rpm and 18 degrees Celsius. Interphase mononuclear cells were removed, then centrifuged again for 5 minutes at 2,000 rpm. The pellet of cells was suspended once again in 1 $\mathrm{mL}$ of PBS.

The cells were counted and their viability was verified using trypan blue. In total, $1 \times 10^{6}$ viable cells were transplanted to the ends of the mandibular cortical sponge autograft.

At first, with the animals under general anesthesia, a portion of around $10 \times 5 \times 5 \mathrm{~mm}$ of cortical sponge autograft from the iliac crest was removed with the help of a tapered diamond drill coupled to a low-rotation motor, and then maintained in a sterile and warm receptacle with saline solution $(\mathrm{NaCl} 0.9 \%)$. Subcutaneous and skin closing was performed with nylon monofilament thread 4-0 adopting simple interrupted suture.

The mandible was accessed through a side extraoral incision. A portion of around 10x5x5 mm of segment between the mandibular symphysis and the first molar was removed with the help of a low-rotation tapered diamond drill, under constant cooling with a saline solution $(\mathrm{NaCl}$ $0.9 \%)$.

After this phase, the bone defect was filled up with graft, which was attached by means of a four-hole no-spacing titanium microplate and two $5 \mathrm{~mm}$ titanium screws - one in the cranial portion of the mandible and one in the following hole in a caudal direction from the first screw this way holding the autograft from iliac crest in place. An additional $7 \mathrm{~mm}$ titanium screw was placed into the last caudal hole of the microplate. At this moment, in the $\mathrm{BMG}, 1 \times 10^{6}$ mononuclear cells extracted from the autogenous bone marrow of the femur were inserted into the autograft from the iliac crest. Lastly, closing was performed with nylon monofilament thread 4-0, adopting simple continuous suture to join tissues and simple isolated stitch suture for skin closing.

On the days following the surgery the animals received analgesics, anti-inflammatory and antibiotics. For the clinical assessment, the animals were inspected daily for the first seven postoperative days. The rabbits' behaviors were observed in terms of returning to commercial feeding, chewing and deglutition restoration, pain and local edema. The radiographic evaluation was performed $0,7,14,21$ and 28 days after the surgery. Two pictures - one $45^{\circ}$ lateral oblique and one mandibular front - were taken.

The following was assessed with the radiographs: alignment of bone graft in relation to proximal and distal mandible segments, microplate instability, migration of screws, and signs of consolidating bone/graft interfaces and bone bridge formation. Radiographic union was considered effective with the presence of complete cortical continuity in bone/graft interface and when both periosteal and endosteal calluses presented active remodeling.

At the end of the assessment periods (15 and 30 days), all animals were euthanized, following the norms of Conselho Federal de Medicina Veterinária for animal euthanasia. After the euthanasia, the operated portion of mandible was assessed for reaction of soft tissues and bone callus quality, signs of infection, as well as aspect and stability of microplate, screws and bone graft. After the microplate and screws were removed, the collected mandible fraction was placed in $10 \%$ buffered formalin solution for histological assessment.

The fixed material remained for the minimum period of 72 hours in formaldehyde, and was later decalcified in a $10 \%$ nitric acid solution. The segments were longitudinally cut and processed via paraffin inclusion method. Histological cuts pf 4 micra thick stained with hematoxylin-eosin were examined in an optical microscope. This analysis verified bone union or nonunion in each interface and measured inflammatory reactions, reabsorption rate and graft revascularization. Table 1 was taken into account for the evaluation of bone union/nonunion. The scale for the assessment of inflammatory reaction, reabsorption rate and graft revascularization was: absent $=0$; modest $=$ 1 ; moderate $=2$; intense $=3$. The radiographics and histological studies were performed by a trained veterinarian not informed as to the treatment's group. 
Table 1. Semi quantitative scale for the histological assessment of the union between the cortical sponge bone graft and the receptor bed in rabbits *

\begin{tabular}{llc}
\hline Region & Histological aspect & Score \\
\hline & Complete nonunion & 0 \\
& Fibrous union & 1 \\
Graft/ receptor interface & Cartilaginous union & 2 \\
& Cartilage with some bone tissue & 3 \\
& Complete bone union & 4 \\
\hline
\end{tabular}

Source: Adapted from Stevenson et al. (1997).

*Each cranial, distal and medial interface was considered separately. The maximum possible score was 12.

At first, a descriptive analysis of variables was performed and the alignment of their distributions was tested in relation to normal distribution $(\mathrm{P}<0.05)$. Quantitative variables were described through median, minimum and maximum values. Categorical variables were described through percentages of absolute frequencies and relative frequencies. They were compared to variables through the KruskalWallis test and, for the revascularization variable, a score conversion was made to apply the Tukey test for multiple comparisons. The significance level of $5 \%$ was considered. Statistical pack SPSS v. 14.0 was used to process the analyses.

\section{RESULTS}

The procedure was effective for bone marrow collection. Bone marrow cell separation produced $10^{6}$ mononuclear cells in all rabbits. During clinical assessments, no change in chewing and deglutition was observed, since the animals ate the commercial ration normally on the first postoperative day. The animals presented no sign of pain or edema in the surgery place.

The formation of adherence in the operated region was observed 15 days after the surgery, when it was possible to identify the bone tissue graft around. In the macroscopic assessment 30 days after the surgery, the tissue still presented adherences. However, no difference was observed between the tissue and the recently formed structure. No mobility was observed between the internal fixing material and the graft, except for one rabbit in control group 15 days after the surgery, which evidenced cranial screw rejection and had to be eliminated between the $7^{\text {th }}$ and $14^{\text {th }}$ postoperative day, with neither graft displacement nor plate stability loss. No sign of contamination, such as the formation of exudation or change in tissue coloring in the region was observed.

Radiographic images taken 7 days after the surgery showed that $14.3 \%$ (4/28) of the animals had increased bone density in the operated region in all the groups analyzed. On the $14^{\text {th }}$ postoperative day radiographs, $85.7 \%(12 / 14)$ of the BMG rabbits had increased bone density in the autograft implantation place, while in the control group $92.8 \%$ (13/14) of the rabbits showed such findings. All 14 rabbits inspected in the postoperative period demonstrated good bone reconstruction progress in the radiographic exam taken 21 days after the surgery, although no bone bridge formation between fragments was observed in any case. The last radiographic analysis performed on the $28^{\text {th }}$ postoperative day showed that $85.7 \%(6 / 7)$ of the BMG animals and $42.8 \%(3 / 7)$ of the $\mathrm{CG}$ animals presented compatible images with a bone bridge joining both graft ends.

Considering the two rabbits in the BMG group with increased bone density on the $7^{\text {th }}$ postoperative day, one did not present the bone bridge formation in the radiographic image made on the $28^{\text {th }}$ postoperative day. The progress of the other animals from the group could not be assessed as it was one of the euthanized rabbits on the $15^{\text {th }}$ postoperative day. In the CG group, only one rabbit presented union of graft ends.

Improved union of graft/bone interfaces occurred in $\mathrm{CG}$ and $\mathrm{BMG}$ animals in an equivalent rate on $15^{\text {th }}$ and $30^{\text {th }}$ day post-surgery. However, there was a high variation of values when comparing animals from the same group (Figure 1). The occurrence of inflammation was the same in both $\mathrm{CG}$ and $\mathrm{BMG}$ groups on the $15^{\text {th }}$ day, with median value representing low inflammatory reaction. In both groups, one month after surgery an inflammatory reaction was not observed. 


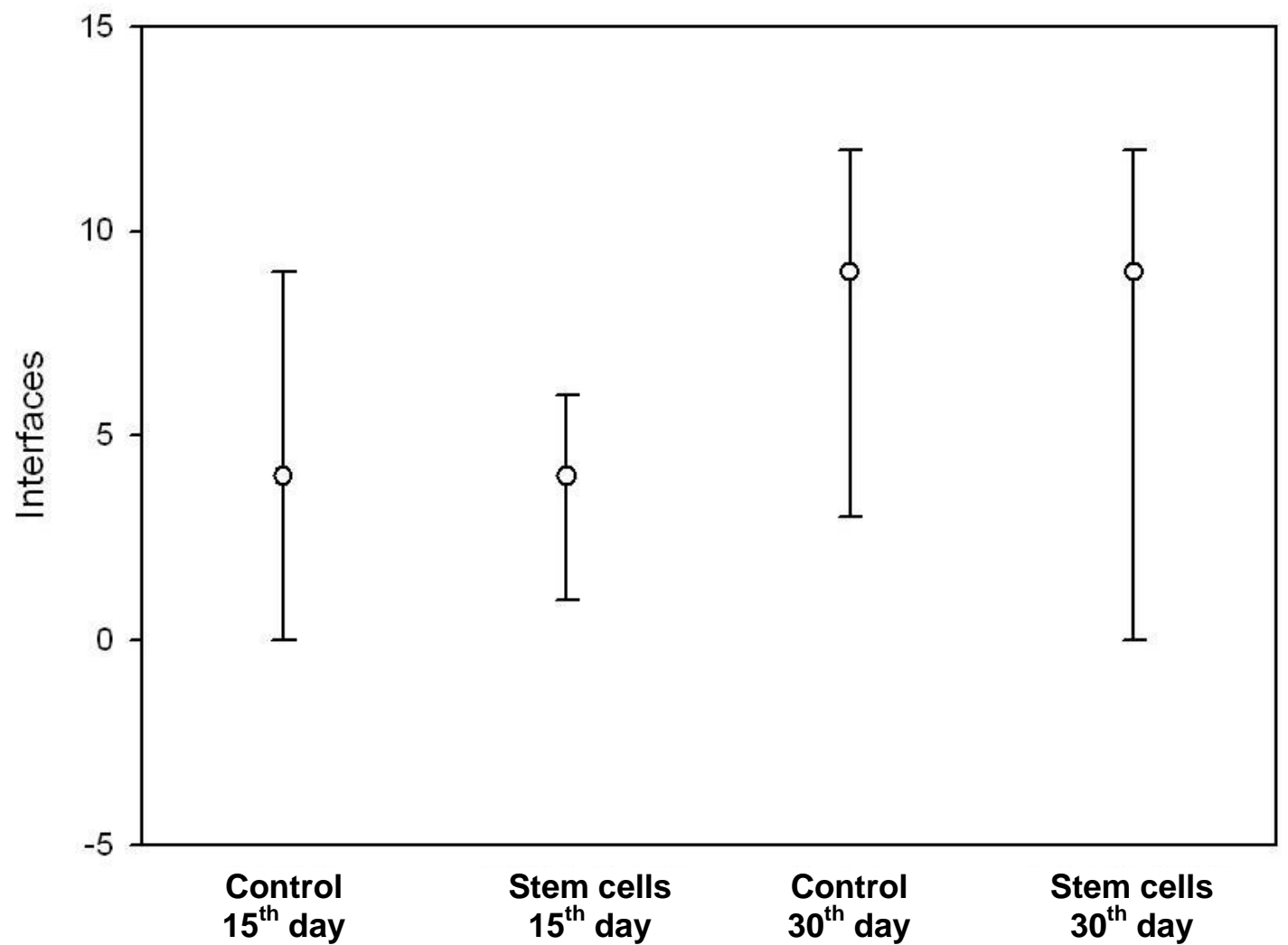

Figure 1. The graph depicts median values of graft/bone interfaces, and max. and min. values obtained in control and experimental rabbit groups.

The reabsorption rate score of the BMG group on the $30^{\text {th }}$ day was 3 , indicating an intense reabsorption rate, while the control group on the $30^{\text {th }}$ day and both groups on the $15^{\text {th }}$ showed a moderate reabsorption rate (score 2). Regarding the graft revascularization rates, The BMG on the $15^{\text {th }}$ day presented a low revascularization rate. Both CG15 and BMG30 presented a moderate revascularization rate and $\mathrm{CG}$ on the $30^{\text {th }}$ day obtained a high revascularization rate.

\section{DISCUSSION}

The mononuclear cell separation was selected because it is an easy and fast method that enables collection, separation and application during the same surgical procedure and allows standardizing of the cell quantity to be implanted in the bone defect. The importance of stem cells in bone regeneration and its relatively low quantity in relation to nucleated marrow cells have directed studies to cell separation, purification and concentration (Barros et al., 2001a). However, no culture, separation and/or differentiation of mesenchymal stem cells were performed, for the reasons mentioned above and to reduce risks of sample contamination during the process.

Stem cell characteristics of cell differentiation in osteogenic lineages, favoring the bone reconstruction (Kraus and Kirker-Head, 2006), led this study to the analysis of bone healing from a mandibular defect by using a cortical sponge autograft associated with mononuclear cells of bone marrow, which could enhance the osteogenic and osteoinducing effects of the "gold standard". Likewise, the use of autogenous iliac crest as a carrier of these cells would prevent the risk of immunological reactions in the tissue.

Two factors encouraged the use of radiographs on the $7^{\text {th }}$ postoperative day: the studies conducted by Barros et al. (2001b) and Del Carlo et al. (2003), which observed early bone reconstruction, and the "gold standard" utilization. However, increased bone density was obtained in only $14.3 \%$ of the rabbits in the 
analyzed period, with no difference between $\mathrm{CG}$ and BMG. These findings did not correspond to a better result at the end of the fourth week, as only one of the three animals presented a bone bridge formation and another one was from the BMG group inspected on the $15^{\text {th }}$ postoperative day.

On the other hand, the two BMG rabbits that did not present increased radio-opacity on the $14^{\text {th }}$ day showed bone bridge formation in the last assessment, showing that the early or late increase in bone density did not correspond to a better reconstruction. It is difficult to explain the reason for these results, as little is known about how the stem cells act on bone reconstruction and when they play a primary or secondary role. They might provide not only bone progenitor cells, but also growth factors that that can modulate osteoinducing action (Rizzo et al., 2005). Or even the process of reabsorption or replacement with bone tissue, when established, might have occurred with a higher number of cells.

The radiographic analysis of the BMG animals performed on the $28^{\text {th }}$ day showed the mandibular defect was filled up with bone callus in both margins, which agrees with the study conducted by $\mathrm{Li}$ and $\mathrm{Li}$ (2005), who used mesenchymal stem cells with differentiated osteoblast in the experimental group. This outcome highlights the advantages of the bone marrow cell transplant group in relation to the control group, with similar results to those from the cultivation and differentiation cell technique.

The healing process progression was confirmed in both groups and no other statistical differences were observed between the two groups, as reported by $\mathrm{Li}$ and $\mathrm{Li}$ (2005). The authors suggested that in animals submitted to cellular therapy, the osteogenesis, osteoinduction and osteoconduction processes occurred simultaneously, while in the control group, the main involved process seemed to be osteoconduction. As this study uses an autograft, these mechanisms are expected to occur in both groups in a similar fashion. However, rabbits with mononuclear cell therapy might have presented a higher number of cells, which collaborated to improved radiographic results of these animals.
The analysis conducted by Portinho (2006) and Yuan et al. (2007) showed that the use of stem cells in bone reconstruction promoted better healing, when compared to the use of carrier substance separately, although the results with autografts were not improved. Such data suggests that, as the defect was filled in with graft regarded as perfect, presenting viable cells, this difference might have not been so considerable. In addition, differences in animals that received mesenchymal stem cells were statically significant only when little or no bone defect reparation was observed in the control groups (Seto et al., 2001; Shang et al., 2001; He et al., 2007). This fact did not occur in the control group in this study.

In terms of graft/bone interface data, the $\mathrm{CG}$ and BMG rabbits analyzed on the $30^{\text {th }}$ day presented improved integration, confirming the healing progress in this period, when compared to the analysis on the $15^{\text {th }}$ day. The CG and BMG, in the exams on both $15^{\text {th }}$ and $30^{\text {th }}$ day, showed the same results, even though no uniformity was observed. It is mainly due to the presence of fibrous, cartilaginous and bone tissue without homogeneous distribution and the different degrees of reconstruction in the same graft and of inflammation observed.

The inflammatory reaction was practically absent in rabbits analyzed on the $30^{\text {th }}$ postoperative day. One BMG animal had intense inflammatory reaction around the graft and was the only one that did not present a bone bridge. The inflammatory process plays a crucial role in the healing process. It takes place in the first moments after the injury occurs, attracting precursors for tissue regeneration, and reduces its activity gradually as the process advances (Stevenson et al., 1997; Hulse and Hyman, 1998; Bauer and Muschler, 2000). However, in this case, there was no progress like in others, due to continuous local inflammation, which might have been caused by a bacterial infection. On the $15^{\text {th }}$ day, this finding was modest, following the normal post-lesion process. Although macroscopically no animal had any sign of inflammation, the histopathological exam showed some cases of intense reaction.

The reabsorption rate was higher in the $\mathrm{BMG}$ on the $30^{\text {th }}$ day than in the others, representing intense cell activity in the graft. The bone matrix 
is reabsorbed by the remodeling process and replaced with bone tissue, which consequently increases bone density (Stevenson et al., 1997; Bauer and Muschler, 2000). This process is essential for the healing process and perhaps, for this reason, the animals in the group treated with cells from the bone marrow suspension showed better radiographic results then the control group in this period.

Revascularization rates were higher in GC15 and GC30 when compared to BMG15 and BMG30. The importance of this formation in the provision of nutrients and cells for the graft has been attested (Stevenson et al., 1997; Bauer and Muschler, 2000). However, the BMG30 animals showed better radiographic results, which may indicate that the irrigation was more effective or that the presence of a higher number of viable cells enabled a quicker reconstruction, regardless of the irrigation. Therefore, the mechanisms of stem cell action on bone reconstruction still have to be better established. Several studies are required to determine the best way to administrate these cells, the most adequate carrier agent, site preparation for implantation and clinical situations in which they should be utilized.

\section{CONCLUSION}

The radiographic exams had evidenced a gradual increase of the bone density of the autograft iliac creast. In the fourth week, the bridge bone formation was bigger in the experimental group. However the histopathological analysis did not show any statistical difference between both groups.

\section{REFERENCES}

BARROS, S.V.S.G.; DEL CARLO, R.J.; VARGAS, M.I. et al. Auto-enxerto percutâneo de medula óssea em coelhos. I. Coleta, preparo e aplicação. Cienc. Rural., v.31, p.1013-1018, 2001a.

BARROS, S.V.S.G.; DEL CARLO, R.J.; VARGAS M.I. et al. Auto-enxerto percutâneo de medula óssea. II. Reparação de falhas segmentares produzidas no rádio de coelhos. Cienc Rural., v.31, p.627-632, 2001b.
BAUER, T.W.; MUSCHLER, G.F. Bone graft materials. Clin. Orthop. Relat. Res., v.371, p.1027, 2003.

DEL CARLO, R.J.; KAWATA, D.; VILORIA, M.I.V. et al. Polímero derivado de mamona acrescido de cálcio, associado ou não à medula óssea autógena na reparação de falhas ósseas. Cienc Rural., v.33, p.1081-1088, 2003.

ELLIS, E. Reconstrução cirúrgica dos defeitos maxilares. In: PETERSON, L.J. (Ed). Cirurgia oral e maxilofacial contemporâneo. 4. ed. São Paulo: Elsevier, 2005. p.681-694.

GANDELMAN, I.H.A.; CAVALCANTI, M.A.A.; FAVILLA E.E. Enxertos e reconstruções ósseas em cirurgia dos tumores odontogenicos e não-odontogenicos. In: CARDOSO, R.J.A.; MACHADO, M.E.L. (Eds.). Odontologia, arte e conhecimento: cirurgia, endodontia, periodontia e estomatologia. São Paulo: Artes Medicas, 2003. p.95-104.

HE, Y.; ZHANG, Z.Y.; ZHU, H.G. et al. Experimental study on reconstruction of segmental mandible defects using tissue engineered bone combined with bone marrow stromal cells with three-dimensional tricalcium phosphate. J. Craniofac. Surg., v.18, p.800-805, 2007.

HULSE, D.A.; HYMAN, B. Biologia e biomecânica das fraturas. In: SLATTER D. (Ed). Manual de cirurgia de pequenos animais. São Paulo: Manole, 1998. p.1891-1900.

JONES, N.C.; TRAINOR, P.A. The therapeutic potential of stem cells in the treatment of craniofacial abnormalities. Expert Opin. Biol. Ther., v.4, p.645-657, 2004.

KRAUS, K.H.; KIRKER-HEAD, C. Mesenchymal stem cells and bone regeneration. Vet. Surg., v.35, p.232-242, 2006.

LI, Z.; LI, Z. Repair of mandible defect with tissue engineering bone in rabbits. ANZ J. Surg., v.75, p.1017-1021, 2005.

PORTINHO, C.P. Reconstrução óssea de calota craniana com enxertos com células-tronco mesenquimais: estudo experimental. 2006. 98f. Dissertação (Mestrado em Cirurgia) - Faculdade de Medicina, Universidade Federal do Rio Grande do Sul, Porto Alegre. 
RIZZO, D.; DEL CARLOS, R.J.; SILVA, A.S.A. et al. Matriz óssea homóloga desmineralizada associada à medula óssea autógena fresca na artrodese vertebral dorsolateral lombar em coelhos. Arq. Bras. Med. Vet. Zootec., v.57, p.163-170, 2005.

SETO, I.; ASAHINA, I.; ODA, M. et al. Reconstruction of the primate mandible with a combination graft of recombinant human bone morphogenetic protein-2 and bone marrow. $J$. Oral Maxillofac. Surg., v.59, p.53-61, 2001.

SHANG, Q.; WANG, Z.; LIU, W. et al. Tissueengineered bone repair of sheep cranial defects with autologous bone marrow stromal cells. $J$. Craniofac. Surg., v.12, p.586-593, 2001.
STEVENSON, S.; LI, X.Q.; DAVY, D.T. et al. Critical biological determinants of incorporation of non-vascularized cortical bone grafts. J. Bone Jt. Surg., v.79, p.1-16, 1997.

SYLVESTER, K.G.; LONGAKER, M.T. Stem cells: review and update. Arch. Surg., v.139, p.93-99, 2004.

YEH, L.S.; HOU, S.M. Repair of a mandibular defect with a free vascularized coccygeal vertebra transfer in a dog. Vet. Surg., v.23, p.281-285, 1994.

YUAN, J.; CUI, L.; ZHANG, W.J. et al. Repair of mandibular bone defects with bone marrow stromal cells and porous $\beta$-tricalcium phosphate. Biomaterials, v.28, p.1005-1013, 2007. 